\title{
Realization of biological productivity of grape varieties in conditions of the south of Russia under influence of shoot load
}

\author{
Galina Aleynikova*, and Olga Seget
}

Federal State Budget Scientific Institution «North Caucasian Federal Scientific Center of Horticulture, Viticulture, Wine-making», 39 str. 40 Let Pobedy, Krasnodar, 350901, Russia

\begin{abstract}
The size of the yield depends on several biological, ecological, and technological factors. Biological factors, such as genotype, as well as environmental factors, such as the weather conditions of the growing season, are unregulated. In our research we were regard the question of the effect of bush shoot load on the realization of biological and managemental productivity of the grape varieties Granatovyi, Antaris and Alcor in the conditions of southern Russia. As a result of the study, the features of the growing season 2020 and their influence on the cluster structure, berry size and cluster weight were noted. A high percentage of fruiting shoots was noted at 100000 and 140000 shoots/ha in the variety Granatovyi (96.8 and $95.3 \%), 140000$ shoots/ha in the varieties Antaris (83.3\%) and Alcor $(92.9 \%)$. It has been revealed that increase in number of shoot load on bushes to $140000 \mathrm{pcs} / \mathrm{ha}$ in the varieties Antaris and Alcor leads to higher yields without quality declining. While in the variety Granatovyi best yields without reducing the quality of grape were observed when the shoot load was $120000 \mathrm{pcs} / \mathrm{ha}$.
\end{abstract}

\section{Introduction}

The agricultural crops have been farming for getting commercially valuable product, in viticulture - it is table grape varieties yield for fresh consumption or technical varieties yield for industrial processing. The yield amount depends on the number of biological, ecological, and technological factors [1,2]. Biological factors are primarily biological characteristics of the genotype - these are varietal productivity indicators such as the optimal number of shoots per bush or per hectare, the percentage of fruitful shoots, fruitfulness coefficients, the average cluster weight [3-5].

The ecological factors are impacted to realization of variety`s biological productivity. Sh. $\mathrm{N}$. Ghuseynov established that the most important period for next year harvesting is time from June to October - correlation coefficient of air temperature with yield capacity index is 0.86 , and of average cluster mass -0.83 at a high probability level. According to E.A. Ribalko and others, the yield amount highest correlation of Muskat White variety is observed with following ecological parameters: minimum air temperature in the second decade of August,

* Corresponding author: gala.aleynikova@gmail.com 
diurnal range of temperature in the second decade of September, effective heat sum in the March and April, precipitation amount in May and January. Moreover, all parameters, except the last, have inverse correlation with yield capacity. The precipitation amount in January has direct relationship with yield amount [6-8].

Due to global climate change, there is current research on the effects of these changes on the grape plant, yield capacity and quality of products around the world. M. Bonada and other, in their research notes that water lack gives rise to coloring substances and increases the aromaticity of the wines, had not affect in high air temperature $[9,10]$.

Technological or anthropogenic factors affecting the value and quality of the yield include cultural practices, planting system, soil management system, canopy management, shoot load and the different green operations (pruning, top removal, defoliation, pinching out). Studies of the impact of technological methods on yield and quality of grapes are numerous and relevant due to the diversity of varieties and different growing conditions [11, 12].

The noteworthy studies of correlation between load, leaf surface and yield capacity have been conducted by A. Dobrei and other for Fetian negro Pinot noir, Cabernet Sauvignon, Merlot, Burgundy and Cadarca varieties. The authors established that optimal bush bud load - 30 pcs. for Cabernet Sauvignon and Pinot noir varieties, 40 pcs. for Fetian negro, Merlot Burgundy and Cadarca varieties. Also, for Cabernet Sauvignon and Pinot noir leaves has been established the sustainable correlation between bud load and leaves surface [13].

In the southern Russia, where concentrate the industrial core vineyards, research is also underway to determine the impact of biological, technological and ecological factors upon grapevine plant, its productivity and wine quality. In this article we consider a current question of realization of grape varieties Granatovyi, Antaris and Alcor biological productivity in Anapa in the Krasnodar region, under the influence of different shoot load on bushes $[14,15]$.

\section{Materials and Methods}

As research objects were used grape varieties of NCFSCHVW breeding - Granatovyi, Antaris and Alcor. The planting scheme was 3,0 x 1,0 м. The variants of load were 100000 , 120000 and 140000 shoots per hectare or 30,36 and 42 shoots per bush, respectively.

Granatovyi, (Saperavi x Cabernet-Sauvignon) - technical grapevine variety, middle-late ripening stage. The cluster are medium and large, broadly conical, or cylindrical-conical, dense, or moderately dense. The berries are medium and small, dark blue with a thick waxy coating. Skin of medium thickness, firm. The flesh is juicy, spreading. Yield capacity is 120$140 \mathrm{~kg} / \mathrm{ha}$. The bushes are medium-height.

Antaris (Saperavi x Tsimlyansky cherniy) - technical grapevine variety, late ripening stage. The clusters are medium and large, average density. The berries are medium size, dark with purine plaque, rounded. The skin is tender, strong. The flesh is juicy. The productivity is high, sustainable from year to year (9-10 kg per bush). The bush's growing power is very high.

Alcor (Serexia x Cabernet-Sauvignon) - technical grapevine variety, middle-late ipening stage. The clusters are medium to large, average density. The berries are small, rounded, dark. The palate is fuller, harmonic with distinctly nightshade flavor. The yield capacity is high $8-10 \mathrm{~kg}$ per bush. The bushes are strong, and the maturation of the shoots is good.

Place of research: Blacksea agroecological zone of the Krasnodar region (Ch2, Anapa, Krasnodar region), soils are humus-carbonate. Agrobiological records were conducted according to generally accepted methods («Methodological and analytical support of organizing and conducting research on the technology of grape production», 2010 г.) The mass concentration of carbohydrates in grapevines wort had been identify by areometer by 
GOST 13192-73. The berry juice acidity was identified by titration method (GOST 516212000).

\section{Results and Discussion}

The vegetation period in 2020 yar was not distinctive to the cultivation region. It had several features such as mild winter, short warming period in Mart to mid-decade temperature 6,8$11,8^{\circ} \mathrm{C}$, low-temperature regime in April with common intense frosts in the air and on the surface of the soil (according to Anapa meteorological station data was observed the frosts in air $\left(1^{\circ} \mathrm{C}\right)$ and on soil $\left(-2^{\circ} \mathrm{C}\right)$ of the dangerous phenomena category (DP)) and insufficient precipitation in summer on the background of high maximum air temperatures. All this had a stressful effect on the grape plant.

To establish the influence of shoot load of bushes on the realization of biological productivity, agrobiologically records were made (tabl. 1)

Table 1. The influence of shoot load of bushes on the realization of agrobiologically records of grapevine, Anapa, 2020 year.

\begin{tabular}{|c|c|c|c|c|c|c|c|c|}
\hline \multirow{2}{*}{ Variety } & \multirow{2}{*}{$\begin{array}{c}\text { Shoot } \\
\text { load, } \\
\text { shoots/ha }\end{array}$} & \multicolumn{2}{|c|}{$\begin{array}{c}\text { Bud number, } \\
\text { pb./bush }\end{array}$} & \multirow{2}{*}{$\begin{array}{c}\text { Devel } \\
\text { oped } \\
\text { buds, } \\
\%\end{array}$} & \multirow{2}{*}{$\begin{array}{c}\text { Fruitf } \\
\text { ul } \\
\text { shoot } \\
\text { s, \% }\end{array}$} & \multirow{2}{*}{$\begin{array}{c}\text { Inflore } \\
\text { cence } \\
\text { number, } \\
\text { pcs/bush }\end{array}$} & \multicolumn{2}{|c|}{$\begin{array}{c}\text { Coefficient } \\
\text { S }\end{array}$} \\
\hline & & $\begin{array}{l}\text { In } \\
\text { total }\end{array}$ & $\begin{array}{c}\text { including } \\
\text { develope } \\
\text { d }\end{array}$ & & & & K1 & K2 \\
\hline \multirow{3}{*}{ Granatovyi } & 100000 & 36 & 31 & 86.1 & 96.8 & 58 & 1.9 & 1.9 \\
\hline & 120000 & 43 & 36 & 83.7 & 86.1 & 60 & 1.7 & 1.9 \\
\hline & 140000 & 51 & 43 & 84.3 & 95.3 & 75 & 1.7 & 1.8 \\
\hline \multicolumn{2}{|c|}{ Average for the variety } & 47 & 37 & 84.7 & 92.7 & 64 & 1.8 & 1.9 \\
\hline \multirow{3}{*}{ Antaris } & 100000 & 34 & 30 & 88.2 & 73.3 & 23 & 0.8 & 1.1 \\
\hline & 120000 & 42 & 37 & 88.1 & 75.7 & 35 & 0.9 & 1.3 \\
\hline & 140000 & 51 & 42 & 82.4 & 83.3 & 42 & 1.0 & 1.2 \\
\hline \multicolumn{2}{|c|}{ Average for the variety } & 42 & 36 & 86,2 & 77.4 & 33 & 0.9 & 1.2 \\
\hline \multirow{3}{*}{ Alcor } & 100000 & 35 & 30 & 85.7 & 86.7 & 38 & 1.3 & 1.5 \\
\hline & 120000 & 43 & 36 & 83.7 & 91.7 & 47 & 1.3 & 1.4 \\
\hline & 140000 & 50 & 42 & 84.0 & 92.9 & 72 & 1.7 & 1.8 \\
\hline \multicolumn{2}{|c|}{ Average for the variety } & 43 & 36 & 84.5 & 90.4 & 52 & 1.4 & 1.6 \\
\hline
\end{tabular}

The percent of developed buds was in a narrow range 83,7 to $88,2 \%$. It's patterns of change under the influence of shoot load it is not available.

The maximal percentage of fruitful shoots in average was noted in the variety Granatovyi - 92.7\%, slightly lower in the varieties Alcor - 90.4\% and Antaris - 77.4\%. The high percentage of fruitful shoots was noted at a load of 100,000 and 140000 shoots/ha in the variety Granatovyi (96.8 and 95.3\%), at a load of 140,000 shoots/ha in the varieties Antaris $(83.3 \%)$ and Alcor $(92.9 \%)$. The fruitfulness coefficient $\mathrm{k} 1$ in average for the varieties had significant difference. The maximum value of coefficient was of Granatovyi variety 1.8, lower in the variety Alcor -1.4 and minimum in the variety Antaris - 0.9. The average values of fruitfulness coefficients $\mathrm{k} 2$ had a similar sequence.

It has been established that, in Granatovyi variety increase of shoot load leads to decrease in fruitfulness coefficient $\mathrm{k} 1$ from 1,9 to 1,7. In Antaris and Alcor varieties, when the shoot load increases, fruitfulness coefficients $\mathrm{k} 1$ and $\mathrm{k} 2$ increase by $0.1-0.4$ points. 
Granatovyi variety stood out by productivity in the growing season of 2020 year in Blacksea agroecological zone - yield capacity was at 115,4 to 130,2 c/ha with yield per bush at 3,8 to $4,6 \mathrm{~kg}$ (tabl. 2).

Table 2. The influence of shoot load of bushes on the realization of yield capacity of grape, Anapa, 2020

\begin{tabular}{|c|c|c|c|c|c|}
\hline Variety & $\begin{array}{c}\text { Load, thousand } \\
\text { pcs./ha }\end{array}$ & $\begin{array}{c}\text { Clusters } \\
\text { number, pcs. }\end{array}$ & $\begin{array}{c}\text { Cluster } \\
\text { weight, g }\end{array}$ & $\begin{array}{c}\text { Yield per } \\
\text { bush, kg }\end{array}$ & Yield, c/ha \\
\hline \multirow{3}{*}{ Granatovyi } & 100 & 58 & 74.8 & 4.3 & 130.2 \\
\cline { 2 - 6 } & 120 & 60 & 76.5 & 4.6 & 137.6 \\
\cline { 2 - 6 } & 140 & 75 & 51.3 & 3.8 & 115.4 \\
\hline Average for the variety & 100 & 23 & 67.5 & 4.3 & 127.8 \\
\hline \multirow{3}{*}{ Antaris } & 120 & 35 & 103.5 & 2.4 & 71.4 \\
\cline { 2 - 6 } & 140 & 42 & 91.3 & 3.6 & 107.5 \\
\cline { 2 - 6 } & 100 & 33.3 & 99.1 & 3.8 & 115.0 \\
\hline Average for the variety & 38 & 54.8 & 2.1 & 98.0 \\
\hline \multirow{3}{*}{ Alcor } & 120 & 47 & 54.5 & 2.6 & 76.9 \\
\cline { 2 - 6 } & 140 & 72 & 72.4 & 5.2 & 156.3 \\
\cline { 2 - 6 } & 52.3 & 60.6 & 3.3 & 98.6 \\
\hline
\end{tabular}

The weather conditions of the growing season 2020 year have an impact on structure of clusters (uncharacteristically loose), berries size (less than average) and cluster weight (less than average). The lowest cluster weight under influence of bush shoot load was at maximum load (140 000 shoot/ha) - 51,3 and 91,3 g in the Granatovyi and Antaris varieties. In these varieties there is a tendency of decrease in the cluster weight due to increase of the shoot load of bushes. Alcor variety had an inverse pattern - when the load was increased per bush from 100000 to 140000 shoot/ha, cluster weight increased from 54,8 to 72,4 g, too.

It has been found that when the shoot load of bushes is increased the carbohidrates mass concentration in grape berries has been reduced in Granatovyi and Antaris varieties (table 3). In Alcor variety this tendency not found.

Table 3. The influence of shoot load of bushes on the sugar content of grape berries and titratable acidity, Anapa, 10.09.2020

\begin{tabular}{|c|c|c|c|}
\hline \multirow{2}{*}{ Variety } & $\begin{array}{c}\text { Shoot load of } \\
\text { bushes, shoots/ha }\end{array}$ & $\begin{array}{c}\text { Mass concentration } \\
\text { of sugars, } \mathrm{g} / 100 \mathrm{~cm}^{3}\end{array}$ & $\begin{array}{c}\text { Mass concentration of } \\
\text { titratable acids } \mathrm{g} / \mathrm{dm}^{3}\end{array}$ \\
\hline \multirow{3}{*}{ Granatovyi } & 100000 & 18.8 & 4.8 \\
\cline { 2 - 4 } & 120000 & 18.5 & 4.8 \\
\cline { 2 - 4 } & 140000 & 17.0 & 4.2 \\
\hline Average for the variety & 18.10 & 4.60 \\
\hline \multirow{3}{*}{ Antaris } & 100000 & 23.2 & 4.1 \\
\cline { 2 - 4 } & 120000 & 19.6 & 5.6 \\
\cline { 2 - 4 } & 140000 & 20.3 & 5.0 \\
\hline Average for the variety & 21.03 & 4.90 \\
\hline \multirow{3}{*}{ Alcor } & 100000 & 17.0 & 5.7 \\
\cline { 2 - 4 } & 120000 & 16.4 & 5.4 \\
\cline { 2 - 4 } & 140000 & 18.5 & 5.4 \\
\hline \multicolumn{2}{|l|}{ Average for the variety } & 17.30 & 5.50 \\
\hline
\end{tabular}




\section{Conclusion}

The realization of biological productivity was studied in Granatovyi, Antaris and Alcor varieties in the unstable conditions of southern Russia under the influence of different shoots load of bushes. The grapevine plant response to stressful conditions of 2020 year vegetation season has been established - change in the structure of the cluster (loosening), reduction in berry size and cluster weight loss.

Indicators of biological productivity of grapes have a dependence on the value of shoot load. The high percent of fruitful shoots was observed at loads of 100,000 and 140,000 shoots/ha in Granatovyi variety (96.8 and 95.3\%), at loads 140000 shoots/ha in Antaris $(83,3 \%)$ and Alcor $(92,9 \%)$ varieties. It was found that the fruitfulness coefficient $\mathrm{k} 1$ of Granatovyi variety have been decreases from 1.9 to 1.7 when the load is increased. In the Antaris and Alcor varieties, when the shoot load of bush is increased, the fruitfullness coefficients $\mathrm{k} 1$ and $\mathrm{k} 2$ increase by $0.1-0.4$ points. The maximum yield was recorded at the load of 120000 shoots/ha in Granatovyi variety, and 140000 shoots/ha in Antaris and Alcor varieties.

We were identified that Antaris and Alcor varieties at the maximum shoot load of bushes given high yield which have the best quality indicators - maximum sugar content and optimum titratable acidity.

\section{References}

1. R. Hall, N. Penke, M. Kriechbaum, S. Kratschmer, V. Jung, S. Chollet, M. Guernion, A. Nicolai, F. Burel, A. Fertil, Á. Lora, R. Sánchez-Cuesta, G. Guzmán, J. Gómez, D. Popescu, A. Hoble, C.I. Bunea, J.G. Zaller. S. Winter, Agric. Syst., 177, 102706 (2020) https://doi.org/10.1016/j.agsy.2019.102706

2. S. Masia, A. Trabucco, D. Spano, R.L. Snyder, J. Sušnik, S. Marras, Agric. Water Manag., 255, 107005 (2021) https://doi.org/10.1016/j.agwat.2021.107005

3. A.M. Maçanita, R. Santos, A.C. Gomes, Aust. J. Grape Wine Res., 4, 450-460 (2018) https://doi.org/10.1111/ajgw.12353

4. L.B. Moreiro, BIO Web Conf., 9, 01023 https://doi.org/10.1051/bioconf/20170901023

5. B. Kamsu-Foguem, A. Flammang, G. Tchuenté-Foguem, Ecol. Inform., 30, 72-81 (2015) https://doi.org/10.1016/j.ecoinf.2015.09.004

6. J. Fritz, M. Athmann, G. Meissner, R. Kauer, U. Geier, R. Bornhütter, H. Schultz, OENO One, 54(2), 373-391 (2020) https://doi.org/10.20870/oeno-one.2020.54.2.2548

7. R.G.V. Bramley, J. Ouzman, M.C. Trought, OENO One, 54(4), 903-917 (2020) https://doi.org/10.20870/oeno-one.2020.54.4.3858

8. E. Neethling, G. Barbeau, C. Coulon-Leroya, H. Quénol, Agric. Forest Meteorol., 276-277, 107618 (2019) https://doi.org/10.1016/j.agrformet.2019.107618

9. G. Gutiérrez-Gamboa,W. Zheng, F. Martínez de Toda, Food Res. Int., 139, 109946 (2021) https://doi.org/10.1016/j.foodres.2020.109946

10. G. Aleinikova, O. Seget, D. Tsiku, Yu. Razzhivina, Fruit growing and viticulture of South Russia, 65 (5), 222-237 (2020) http://doi.org/10.30679/2219-5335-2020-5-65222-237

11. L.G. Santesteban, Food Chem., 279, 58-62 (2019) https://doi.org/10.1016/j.foodchem.2018.11.140

12. A. Gautier, S.J. Cookson, L. Lagalle, N. Ollat, E. Marguerit, OENO One, 54(1), 1-13 (2019) https://doi.org/10.20870/oeno-one.2020.54.1.2458 
13. G. Aleinikova, Fruit growing and viticulture of South Russia, 53 (5), 51-58 (2018) http://doi.org/10.30679/2219-5335-2018-5-53-51-58

14. T. Verdenal, Á. Dienes-Nagy, J.E. Spangenberget, V. Zufferey, J.L. Spring, O. Viret, J. MarinCarbonne, C. van Leeuwen, OENO One, 55 (1), 1-43 (2021) https://doi.org/10.20870/oenoone.2021.55.1.3866

15.Zs. Zsófi E. Tóth, D. Rusjan, B. Bálo, Sci. Hortic., 127(4), 494-499 (2011) https://doi.org/10.1016/j.scienta.2010.11.014 